\title{
EFFECTS OF CONSUMERS' TRUST AND ATTITUDE TOWARD ONLINE SHOPPING
}

\author{
${ }^{1}$ Mohammad Al-Nasser, ${ }^{1}$ Rushami Zien Yusoff, ${ }^{2}$ Rabiul Islam and ${ }^{1}$ Abdullah ALNasser \\ ${ }^{1}$ School of Business Management, College of Business, University Utara Malaysia, Malaysia \\ ${ }^{2}$ School of Economics, Finance and Banking, College of Business, University Utara Malaysia, Malaysia
}

Received 2014-06-02; Revised 2014-06-08; Accepted 2014-07-11

\begin{abstract}
This study investigated the effects of consumers' trust and attitude toward online shopping. Attitude is referred to as a positive or negative evaluation of people, activities, ideas, objects, event, or just about anything in the environment. Different facets of the e-shopping behavior of consumers have been investigated in previous literature. These facets can generally be divided into three namely, behavioral intention, actual behavior and attitude toward behavior. The aim of the study is to determine the effect of consumers' trust and attitude toward online shopping. A quantitative research design was adopted to collect data. Multiple regression analysis method was used to conduct this study. The findings of the study will contribute to both theory and practice. The results of this study have important contributions and implications for practitioners and policy-makers. This study contributed to the field of consumers' trust and attitude relationship with online shopping in the context of developing countries. It is contended that the examination of the effects of consumers' trust and attitude toward online shopping is more significant than the examination of a direct relationship, which is quite obvious.
\end{abstract}

Keywords: Consumer, Trust, Attitude, Online Shopping, E-Service Quality

\section{INTRODUCTION}

Attitude is referred to as a positive or negative evaluation of people, activities, ideas, objects, event, or just about anything in the environment (Zimbardo and Boyd, 1999). In the view of Bain (1929), an attitude is the relatively stable overt behavior of a person, which affects his/her status. For Lumley (1928), an attitude is a susceptibility to certain kinds of stimuli and readiness to respond repeatedly in a given way, which are possible toward our world and the parts of it, which impinge upon us. North (1932) defined attitude as the totality of those states that lead to or point toward some particular activity of the organism. The attitude is, therefore, the dynamic element in human behavior, the motive for activity. Most attitudes are considered a result of experience or observation from the environment.

Different facets of the e-shopping behavior of consumers have been investigated in previous literature.
These facets can generally be divided into three namely, behavioral intention, actual behavior and attitude toward behavior. Some studies dedicated to the topic consider intention to e-shop as a dependent variable (Choi and Geitsfeld, 2004), while other studies chose actual eshopping behavior as the dependent variable (Eastin, 2002). Some other studies examined the multiple dependent variable determinants with the inclusion of both behavioral intention and actual behavior (Liang and Lai, 2002). Additionally, as attitude results in behavior, some studies viewed attitude towards eshopping as a dependent variable (Childers et al., 2001).

Fishbein (1963) asserted that judgments would consequently transform into consumer attitudes toward the object and lead to consumer's purchase behavior. Similarly, Hassanein and Head (2007) stated that attitude is interlinked with behavioral intention during voluntary technology adoption. Chang et al. (2005) reviewed many studies regarding online attitudes and

Corresponding Author: Mohammad Al-Nasser, School of Business Management, College of Business,

University Utara Malaysia, Malaysia 
intention. They found that in all studies there were significant positive impacts between attitude and intention. It is predicted that consumer attitudes will impact e-shopping intention and result in transaction or the lack thereof ( $\mathrm{Li}$ and Zhang, 2002).

Li and Zhang (2002) conducted a review of online shopping attitude studies and found that studies on the topic have contributed significantly to the explanation of online shopping. Nevertheless, there is still lack of clear understanding of the effects of significant factors on online attitudes and unclear determination of dependent as well as independent variables that limit comparison across studies and lead to elusive synthesis and integration of the empirical literatures.

Finally, Cheung et al., (2003) highlighted the theories used by researchers in 351 papers included in the survey of online consumer behavior research studies. Their findings revealed that Theory of Reasoned Action (TRA) and its related theories with the inclusion of the Technology Acceptance Model (TAM) and Theory of Planned Behavior (TPB) dominated the rest of the theories in the field. Based on the discussion above in this study, researcher considered attitude toward shopping online as the dependent variable.

\subsection{Attitude Towards Behavior}

The first construct in theory of planned behavior is attitude towards a target behavior. An attitude is defined as the extent to which an individual has a favorable or unfavorable evaluation or appraisal of the behavior in question (Ajzen, 1991). Theory of planned behavior considers attitude as a function of information or beliefs that are significant to the target behavior. People generally develop perceptions regarding the behavior related to a particular outcome or to some attributes (e.g., the cost to conduct the behavior) that are significant to them. When people believe that behaviors are associated with desirable outcomes, favorable attitudes toward behaviors are developed.

Attitude theory says there is or might be a causal influence of attitude on behavior (attitude $\rightarrow$ behavior) (Assael, 1995). This is one reason for the popularity of the attitude concept in marketing theory and practice. If this hypothetical causal relation really exists, then it is possible to explain and forecast a person's behavior by analyzing his/her attitude. Furthermore, it is possible to use this relation to change a person's behavior by changing his/her attitude.

Rosenberg and Hovland (1960) argued that for certain types of studies it might be enough to use a single response as the index of an individual's attitude. Thus, when attitudes are studied what are observed are the evoking stimuli on the one hand and the various types of responses on the other. The kinds of responses that are usually utilized as indices of attitudes can be categorized into three: Cognitive, affective and behavioral and it has been proposed that it is more feasible to measure attitude through many dimensions (Rosenberg and Hovland, 1960). From this perspective, it has been argued that a single evaluative score that only assesses the affective component well not represent the complexity of the attitude and that attitude should thus be measured via multi-dimensional constructs (Ajzen and Fishbein, 2005). Pike (2008) proposed that measurement of tourist attitudes should comprise cognitive, affective and conative components. According to Pike, the cognition is the aggregate of what is known or believed regarding a destination and the knowledge related to the destination, which may or may not have been developed from the prior visit and signifies awareness. On the other hand, affect signifies an individual's feelings regarding the object which may or may not be favorable or neutral (Fishbein, 1967), while the component of conation of attitude is the same as the behavior since it is regarded as the intention or action.

Under the view of single dimension, the cognitive and conative components are taken out of attitude where cognition is referred to as beliefs and attitude as intentions and behavior in Fig. 1. Therefore, the single dimensional view is that attitude has a single dimension comprising only a single component referred to as affect, which signifies the level of favorability or unfavorability of the attitude object. Other beliefs and behavioral dimensions are not viewed as attitude components but are instead considered as antecedents or outcomes of attitude (Fishbein and Ajzen, 1975). In sum, while the tripartite approach includes the notion of consistency of the components, the single dimension approach postulates a causal flow through the components and hence, the consistency.

\subsection{Theory of Reasoned Action}

Theory of Reasoned Action (TRA) by Ajzen and Fishbein (1980) was developed from previous research on attitude and behavior. The theory was proposed to address the disadvantages of the traditional attitudebehavior studies, which found weak correlations between attitude toward the object measures and behavior performance (Hale et al., 2002). The key suggestion following theory of reasoned action is the expectation of behavioral intention. 
Theory of Reasoned Action (Fig. 2) provides an explanation of the psychological process of the conscious human behavior and it attempts to clarify determinants of behavior (Ajzen and Fishbein, 1980). Based on this theory, the intention behind an individual's behavior affect the actual performance of the behavior and attitudes towards the subjective norms, in which behavioral intention is the measurement of the extent of people's inclination to exert effort, or their plan to exert effort for the performance of behavior (Ajzen, 1991). An individual's behavioral intention generally has a positive effect on the intended behavior performance. The attitude of an individual towards behavior consists of the evaluation of his/her beliefs while his/her subjective norms are reflected through the normative beliefs concerning the behavior's feasibility evaluated by the referent people and the individual's inclination to follow the beliefs. Moreover, Theory of Reasoned Action postulates that external factors such as the characteristics of the individual indirectly affect his/her behavior through the impact of both attitudes and subjective norms.

According to Vijayasarathy (2002), there exist four types of salient beliefs that can collectively be used to highlight a person's attitude toward e-shopping, namely, product perception, shopping experience, customer service and consumer risk. Theory of Reasoned Action was adapted in the study conducted by Cho (2004) and Verhoef and Langerak (2001) in an attempt to examine e-shopping behavior. Specifically, Cho (2004) contended that attitude toward e-shopping can be shown through the following factors: Perceived outcome of eshopping, previous behavior and attitude toward channels of shopping. The possibility of backing down of any online transaction planned is determined through the aggregate dimensions coupled with the attitude toward e-shopping. On the other hand, Verhoef and Langerak (2001) considered the innovation diffusion theory constructs and hypothesized that an individual's intention to e-shopping is reflected through his/her perceptions of the following: The relative advantage of e-shopping and e-shopping compatibility and complexity. In these studies, subjective norms were not included as determinants of behavioral intention (Fishbein and Ajzen, 1975).

Theory of Reasoned Action (TRA) proposed by Ajzen and Fishbein (1980) is a commonly employed theory in marketing studies. It advocates that a person's behavior is reflected through his/her intentions, which can be predicted from his/her attitudes concerning the behavior and subjective norms. Based on the line of predictions, the attitudes of an individual may be predicted through his/her beliefs concerning the outcome of the behavior. Theory of Reasoned Action is a broad theory and it does not pinpoint particular beliefs that may be important in specific situations. It is utilized for the prediction of different behaviors including finance, marketing, health etc. Therefore, Theory of Resound Action is suitable to be used in the context of online shopping studies via a specific web vendor. Based on the discussion above, researcher used Theory of Reasoned Action as a base theory for the present study.

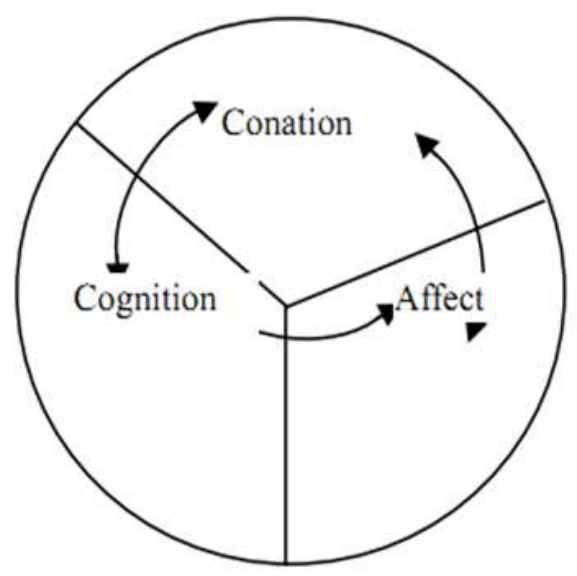

Fig. 1. Simple representation of tri-component attitude model Source: Schiffman et al. (2007)

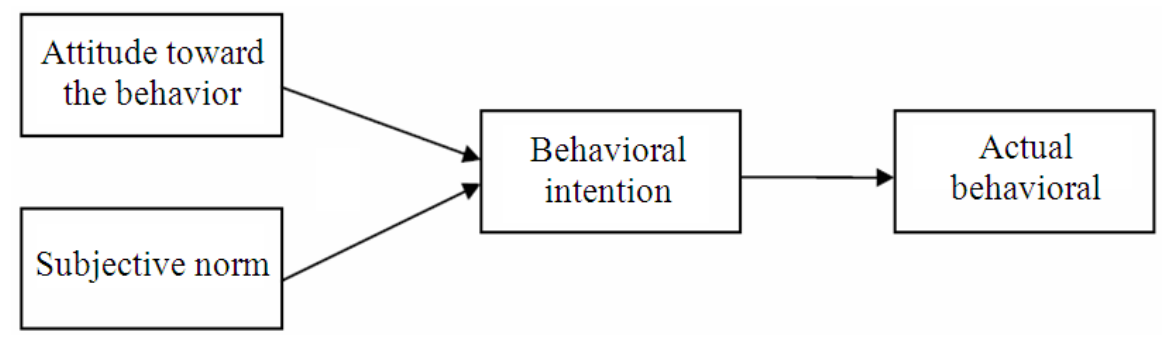

Fig. 2. Theory of reasoned action source (Davis et al., 1989) 


\section{MATERIALS AND METHODS}

A survey approach has been widely used in marketing research to obtain raw data from large groups of people (Cooper and Schindler, 2006). Babbie (2004) found that a survey is the tool most often used as a strategy in business and social researches. The major advantages of employing a survey include: The ability to collect data from large sample sizes at relatively low costs; the capability to identify factors related to the context of issue; and to measure perception and behavior by using relevant instruments (Likert scale) (Hair et al., 2000). A survey also allows collection of standardized common data as respondents give answers to the same fixed-response questions that allow direct comparisons between responses (Saunders et al., 2003). This fixedpattern of responses can facilitate the use of statistical analyses. Thus, a survey is considered the most appropriate data collection method for this study.

Hair et al. (2000) suggested that the choice of survey methods tends to vary according to several factors, which are usually based on the type of data required (e.g., quantitative, qualitative), the budget of available resources, the completion time frame and the requirement of quality data (e.g., generalization). As this study aims to make predictions about consumers' attitude and given the context of this study, quantitative data collected via survey seemed to be the most optimum and suitable method to use.

\subsection{Attitude Measurement Instrument}

There are different attitude models; each one of them describes one or the other component of attitude. Not a single model can be the right model or the absolute model for all research works as each model has its own strengths and weaknesses. They do not provide answers but insights although these models can assist in describing attitudes so that marketers are in a convenient position to clarify and provide predictions regarding the target customers' attitudes and eventually their purchase behavior.

Attitude has been described as a construct that is complex and multi-dimensional that consists of cognitive, affective and conative elements (Krech, et al., 1962). On the basis of this point of view, it is evident that a single evaluative score is insufficient to present the complexity of the attitude construct. Behavior inconsistencies are ready justification for observed attitude; it has been argued that the acquired attitude measures only conducted an assessment of one of the three elements namely cognitive, affective and behavioral (Ostrom, 1969).

Another notable issue is that most attitude measure approaches lead to one score representing the entire positive/negative reaction of the respondent to the attitude object. Many theorists opined that this perspective on a single, evaluative dimension does not provide a complete view of the attitude construct's complexity (Ajzen and Fishbein, 2005). Shimp and Kavas (1984) further suggested that attitude should be separated into cognitive, conative and affective components. The current study utilizes the tri-component attitude model from the field of e-shopping to hopefully better measure attitude by including the three components. In addition, the current study attempts to contribute to literature by studying the many dimensions of attitude towards online shopping.

For the measurement of distinct elements of attitude components, the semantic differential scale developed by Osgood et al. (1957) is the most suitable attitude measurement. Semantic differential method is considered to be simple, flexible and economical in terms of obtaining the responses of people to various attitudinal objects (Heise, 1970). Hence, attitude instrument developed through semantic differential scale is able to measure distinct elements of three components with a set of semantic differential scales that corresponds to the elements.

In this study, items were adapted from Sun et al. (2011) who measured attitude toward varying online security measures. Table 1 shows the dimensions and reliability of the attitude as stated by Sun et al. (2011) while Table 2 shows attitude dimensions and items used by Sun et al. (2011) originally proposed instrument to encapsulate the three attitudes dimensions to various concepts comprising 14 semantic differential items, each with its pair of bi-polar adjectives. Attitude measurement is carried out with the help of a sevenpoint scale, requesting the respondent to rate the possibility of each outcome (Ajzen and Fishbein, 1980). Respondents are requested to pick the place indicating the nearest suitable adjective. For scoring purposes, a numerical score is assigned to each position on the rating scale. Traditionally, score ranges such as $1,2,3,4,5,6,7$ or $-3,-2,-1,0,+1,+2,+3$ are used, in this study scale ranges from -3 to +3 has been used. The average score is computed for every respondent to measure the overall attitude toward the object. This process is chosen as it produces reliable and valid attitude estimation (Smith and Swinyard, 1983). 
Table 1. Attitude measurements

\begin{tabular}{|c|c|c|c|c|}
\hline Construct & Authors & Dimensions & Coefficient alpha & No. of items \\
\hline \multirow[t]{3}{*}{ Attitude } & Sun et al. (2011) & Behavioral & 0.826 & 2 \\
\hline & & Affective & 0.826 & 6 \\
\hline & & Cognitive & 0.923 & 6 \\
\hline
\end{tabular}

Table 2. Items in attitude measurements

\begin{tabular}{|c|c|c|}
\hline \multicolumn{3}{|c|}{$\overline{\text { Behavioral }}$} \\
\hline 1 & I am ___ to shop online: & Inclined--------------------Disinclined \\
\hline 2 & I am___ to shop online: & Eager----------------------Hesitant \\
\hline \multicolumn{3}{|r|}{ Lager-gate- } \\
\hline 4 & I feel ___ toward online shopping: & Like-----------------------------Dislike \\
\hline 5 & I feel like ___ toward online shopping: & Accepting--------------------Rejecting \\
\hline 6 & I feel ___ while using online shopping: & Relaxed------------------------Tensed \\
\hline 7 & I feel ___ while using online shopping: & Excited----------------------------Bored \\
\hline 8 & I feel ___ with the online shopping security: & Content-----------------------Annoyed \\
\hline 9 & I feel ___ with the online shopping security: & 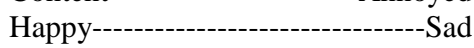 \\
\hline \multicolumn{3}{|c|}{ Cognitive } \\
\hline 10 & I believe that online shopping is___ & Useful--------------------------Useless \\
\hline 11 & I believe that online shopping is & Perfect-----------------------Imperfect \\
\hline 12 & I believe that it is ___ to shop online: & Easy---------------------------Difficult \\
\hline 13 & I believe that it is __ to shop online: & 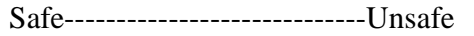 \\
\hline 14 & I believe that adopting online shopping is & 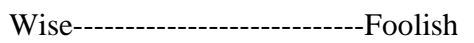 \\
\hline 15 & I believe that adopting online shopping is & Beneficial------------------Harmful \\
\hline
\end{tabular}

\subsection{Trust Measurement Instrument}

Researchers have defined trust in varying ways. It has been acknowledged that trust is challenging to define and to measure (Corritore et al., 2003). Jarvenpaa (2000) defined trust in Internet businesses as the willingness of the consumer to rely on the seller and interact in situations where action makes the consumer exposed to the seller's machinations. Trust exists in risky and doubtful situations (Mayer et al., 1995). Some of the recommended definitions targeted the element of risk existence (Johnson-George and Swap, 1982) while others concentrated on one of the parties' vulnerability (Boss, 1978). Others targeted the existence of clear motivation (Kee and Knox, 1970). In online shopping context McKnight and Chervany (2001) described trust as a belief about online merchant he defined trust as "the belief that the Internet shopper has in an Internet merchant and is willing to engage in an Internet shopping transaction, even with the possibility of loss, based on the expectation that the merchant will engage in generally acceptable practices and will be able to deliver the promised products or services". The view taken up in the present research is the online store through website wherein trust is required to be encouraged between suppliers and consumers if commerce over the web is to continue thriving (Sivasailam et al., 2002).
In the present study, the trust measure was employed from Harris and Goode (2004) with acceptable reliability as shown in Table 3. Harris and Goode based their study on Hess (1995) who was the first to determine customer's trust in car sales in traditional commerce. Table 4 shows items used by Harris and Goode used in this study to measure trust in online shopping. They argued that the Hess (1995) measure of perceived brand trust is a trust measure that is easily transferable and adaptable to online situations. In addition, this scale was used to measure e-trust in previous studies (Rocereto and Mosca, 2012). Responses were scored along a seven-point Likert scale, where -3 indicated that respondents strongly disagreed with the provided statement while +3 presenting that they strongly agreed with it.

\subsection{Instrument Reliability and Validity}

The research instrument's reliability and validity are imperative when carrying out any research. According to Edwards and Talbot (1999), the validity information has its basis on the level to which the method chosen collect information the way it was originally expected. Validity refers to the degree to which a study is not controlled by any interference, ambiguity, control or variable manipulation (Sarantakos, 1997). The instrument's reliability is defined as the level to which the instrument produces the same outcome every time the trial is repeated (Carmines and Zeller, 1979). 
Table 3. Trust measurements

\begin{tabular}{|c|c|c|c|c|}
\hline Construct & Authors & Dimensions & Coefficient alpha & No. of items \\
\hline Trust & Harris and Goode (2004) & Uni-dimensional & 0.814 & 8 \\
\hline \multicolumn{5}{|c|}{ Table 4. Trust items } \\
\hline No & \multicolumn{4}{|l|}{ Items } \\
\hline 1. & \multicolumn{4}{|c|}{$\begin{array}{l}\text { E-retailer is interested in more than just selling me goods and making a profit. In other word, } \\
\text { e-retailer tries to make me happy. }\end{array}$} \\
\hline 2. & \multirow{2}{*}{\multicolumn{4}{|c|}{$\begin{array}{l}\text { There are no limits to how far e-retailer will go to solve a service problem I may have. } \\
\text { E-retailer is genuinely committed to my satisfaction. }\end{array}$}} \\
\hline 3. & & & & \\
\hline 4. & \multicolumn{4}{|c|}{ Most of what e-retailer says about its products is true. } \\
\hline 5. & \multicolumn{4}{|c|}{ I think some of e- retailer's claims about its service are exaggerated. } \\
\hline 6. & \multicolumn{4}{|c|}{ If e-retailer makes a claim or promise about its product, it's probably true. } \\
\hline 7. & \multicolumn{4}{|c|}{ In my experience e- retailer is very reliable. } \\
\hline 8. & \multicolumn{4}{|c|}{ I feel I know what to expect from e-retailer. } \\
\hline
\end{tabular}

The reliability and validity of the instruments are ensured through various ways. Among these ways is the development of suitable data collection and analysis methods. A pilot study entails the involvement of a small number of individuals and the aim behind it is to develop, adapt and ensure that the selected methods are feasible. In this research, the pilot study comprised 32 postgraduate students of Qassim University. The quality of the instruments and the questionnaire translation were ensured in light of the questions' precision, content and suitability. According to Fraenkel and Wallen (2003), the quality of the instrument utilized in any study is imperative as the data acquired through them are used to draw conclusions. When the researcher knows of any potential errors through a pilot study, a solution can be employed instead of wasting any resources by conducting data collection characterized by lack of reliability and validity.

A data collection instrument is deemed dependable when it provides the same results consistently when used in the same sample or different samples of similar size selected from the same population (Tull and Albaum, 1973). In addition based on Fraenkel and Wallen (2003), an instrument is considered reliable if it provides similar results. Reliability is described as the precision of the measurement. In the present study, the questionnaire's reliability was tested through Cronbach's alpha commonly known as alpha coefficient to determine the instrument's internal consistency. Based on Sekaran (2003), reliability coefficient is better if it is closer to 1.00. Generally, the acceptable alpha coefficient should be higher than 0.7. She added that a Cronbach's alpha of 0.6 is low but it is still considered acceptable.

A pilot study was conducted to confirm the reliability of the measurement. The result of the reliability analysis is depicted in Table 5. The table lists the Cronbach's alpha value for every dimension under study. The values of attitude, trust, risk, electronic service quality and culture came out to be $0.865,0.815,0.797,0.938$ and 0.782 , respectively, implying that all variables showed reliability and were suitable for further analysis.

As stated above, validity test ensures that the instrument measures what it is meant to measure. In the present study, validity tests were conducted in the form of face validity. For face validity, the questionnaire was checked by an expert in the marketing field to confirm the items' ability to measure the variables.

The pilot study also revealed several insights to the researcher. During the pilot study, many insights into the web information-seeking attitude were obtained by the researcher. In addition, the reactions of the respondents towards the pilot study helped in many ways; for instance, students' reactions to it showed their misunderstanding of the terms "people in high level" and "people in low level". Hence, the clarification of concepts was made prior to distributing the final questionnaires to the respondents. Observations such as this one resulted in the final questionnaires' revision.

Overall, the researcher was successful in restructuring the questionnaire and devising better ways to connect with the target population. Testing the research instrument beforehand pinpointed the weaknesses of the instrument and resolved the problems of respondents being unaware of the instructions written on the questionnaire. According to Bechhofer and Patterson (2000), an effective research design is one that provides the researcher confidence in the authenticity of the conclusion obtained from the data. To achieve this, a great deal of control is required. This invaluable consideration is highlighted through the adoption of an extensive sampling method ensuring full representation of demographics. The present study employed a comprehensive sample to counteract the lack of in-depth knowledge concerning the study population. 
Table 5. Cronbach's alpha values for each dimension result from pilot test

\begin{tabular}{|c|c|c|c|c|c|}
\hline Construct & Instrument & Dimensions & Original alpha & Alpha (pilot test) & No. of items \\
\hline \multirow[t]{3}{*}{ Attitude } & \multirow[t]{3}{*}{ Sun et al. (2011) } & Behavioral & 0.826 & 0.837 & 2.000 \\
\hline & & Affective & 0.826 & 0.811 & 6.000 \\
\hline & & Cognitive & 0.923 & 0.727 & 6.000 \\
\hline \multirow[t]{5}{*}{ Culture } & \multirow[t]{5}{*}{ Yoo et al. (2011) } & Power distance & 0.910 & 0.534 & 5.000 \\
\hline & & Uncertainty avoidance & 0.880 & 0.841 & 5.000 \\
\hline & & Individualism & 0.850 & 0.828 & 6.000 \\
\hline & & Long-term orientation & 0.790 & 0.888 & 6.000 \\
\hline & & Masculinity & 0.840 & 0.709 & 4.000 \\
\hline Perceived risk & Sitkin and Weingart (1995) & Uni-dimensional & 0.750 & 0.815 & 3.000 \\
\hline E-Service Quality & Parasuraman et al. (2005) & Efficiency & 0.940 & 0.852 & 8.000 \\
\hline (E-S-QUAL Scale) & & System availability & 0.830 & 0.608 & 4.000 \\
\hline E-Service Quality & & Fulfillment & 0.890 & 0.713 & 7.000 \\
\hline \multirow[t]{4}{*}{ (E-RecS-QUAL Scale) } & & Privacy & 0.830 & 0.874 & 3.000 \\
\hline & & Responsiveness & 0.880 & 0.890 & 5.000 \\
\hline & & Compensation & 0.770 & 0.796 & 3.000 \\
\hline & & Contact & 0.810 & 0.903 & 3.000 \\
\hline Trust & Harris and Goode (2004) & Uni-dimensional & 0.814 & 0.797 & 3.000 \\
\hline
\end{tabular}

\section{RESULTS}

\subsection{Normality}

Normality is the most fundamental assumption in multivariate analysis (Hair et al., 2010). It measures whether differences revealed between the obtained and predicted scores of dependent variables (Stewart, 1981). The study sample was taken from the population, it is crucial to compare the sample normal distribution to one of the basic social science measurements, namely, the normal distribution of the population. The normal density function is described as a bell-shaped distribution that is symmetric to the values surrounding the mean.

To check for normality, four measures were used in this study to measure and assess the spread of data distribution: Standard deviation, mean, skewness and kurtosis.

In the present study, the entire variables were tested for normality where the values of skewness and kurtosis were examined to test the scores of normality. Table 6 shows that the overall the values of skewness and kurtosis were within the critical value. Hence, the possibility of issues surrounding non-normal distribution appeared to be insignificant.

\subsubsection{Attitude}

Fishbein and Ajzen (1975) provided one of the most well-known definitions of attitude. According to them, attitude is, "a learned predisposition to respond in a consistently favorable or unfavorable manner with respect to a given object" (p. 6). Later, Ajzen (1988) defined attitude as "a disposition to respond favorably or unfavorably to an object, person, institution or event or to any other discriminable aspect of the individual's world". According to Ajzen (1989), formal definitions proposed for attitude may vary, but most social psychologists are of the consensus that the characteristic attribute of attitude is its nature of evaluation. This is supported by the fact that the standard attitude scaling methods reveal a score that specifies an individual on an evaluative dimension with the attitude object. It is imperative to keep in mind that based on the theory, attitude is referred to as a function of beliefs that are unique to the individual. It is natural to perceive attitudes from the responses to many kinds of belief statements, but only those beliefs that are unique in the mind of the individual are thought of as having a causal effect on attitudes (Fishbein and Ajzen, 1975).

Regarding attitude measurement, it has been argued that a single evaluative score that only assesses the affective component does not represent well the complexity of attitude. Hence, it should be measured via multi-dimensional constructs (Ajzen and Fishbein, 2005), with the first being the tripartite concept of attitude, aptly named as it specifies three components of attitude namely cognition, affect and conation. The first component is comprised of information and perceptions that are found through a combination of experiences with the attitude objects and related information from different sources. The second component covers an individual's feelings regarding the attitude object while the third one deals with the possibility that an individual will show a particular behavior to the attitude object (Schiffman and Kanuk, 2004). 
Table 6. Normality test results

\begin{tabular}{llllll}
\hline & $\mathrm{N}$ & Mean & Std. deviation & Skewness & Kurtosis \\
\hline Attitude & 414 & 4.78 & 1.35 & -0.500 & -0.70 \\
Risk & 414 & 4.72 & 1.54 & -0.500 & -0.75 \\
Trust & 414 & 3.50 & 1.36 & 0.270 & -0.66 \\
E-sq & 414 & 3.52 & 1.43 & 0.500 & -0.60 \\
Culture & 414 & 3.47 & 1.09 & 0.005 & -0.24 \\
\hline
\end{tabular}

\subsubsection{Trust}

Trust is a relatively old concept in the view of business practitioners. It is a critical construct in buyer-seller relation (Morgan and Hunt, 1994). Trust is also an important construct in the context of marketing. As stated by Berry and Parasuraman (1991), customers generally buy products after experiencing trust. Mayer et al. (1995) defined trust as "the willingness of a party to be vulnerable to the actions of another party based on the expectation that the other party will perform a particular action important to the trustor, irrespective of the ability to monitor or control that other party". On the basis of the above conceptualizations, trust can be considered as a trustor's (consumer) inclination to depend on the trustee and to decide on taking an action in a risk laden situation whereby the trustor becomes vulnerable to the trustee (online seller), in the hope of a positive outcome.

Researchers have conceptualized trust in a global way and considered its many dimensions. For instance, Doney and Cannon (1997) study initially proposed that trust had a two-dimensional composition (credibility and benevolence). However, their results later showed that trust emerged as unidimensional global concept. Another study supporting the uni-dimensionality perspective of trust was conducted by Joshi and Stump (1999). In their study of joint action in manufacturer-supplier relationships, supplier trust was treated as a uni-dimensional concept. By comparing the results of measurement models with a series of 10 different alternative measurement models using multi-dimensional trust components, the single-dimension trust scale used in their research had the best measurement properties.

\section{DISCUSSION}

\subsection{Reliability of Measures}

Reliability refers to whether or not the measurement scale is characterized by consistency and stability. A research instrument's reliability is defined as the concerns to the degree to which the instrument produces the same results in repeated cases (Carmines and Zeller, 1979). It presents the level to which the respondent answers the same or similar questions consistently every time (Cronbach, 1951). It is the function that a researcher should consider as a fundamental requirement prior to proceeding with the data analysis and interpretation. Reliability is confirmed as a necessary target that is considered as a validity criterion (Crocker and Algina, 1986).

Two measures are used to evaluate reliability namely Cronbach's alpha $(\alpha)$ and item-to-total correlation. Cronbach's alpha, named after Cronbach (1951), is described as a measure that provides an idea as to the internal consistency by presenting the way items are used to measure some constructs of interest by examining the proportion of times variance compared to common known figures. Cronbach's alpha is considered high if the correlation between particular items increases. Items having low correlation values should be eliminated under particular conditions as they might lessen the total relationship value within a single set of items; in other words, low correlation value items are invalid to use.

Because the measurement scales in the present study consisted of items previously tested in different studies, the scales need to be "purified" prior to conducting any analysis. This purification of scales involved calculating the alpha scores of every scale and deleting indicators having low reliability when they were deemed as not representing a distinct and significant theoretical dimension (Moorman et al., 1992; Pritchard et al., 1999). In the present study, the reliability of the instruments used was examined using Cronbach's alpha. Generally, the measurement scales showed good performance with Cronbach's alpha values higher than 0.7 for all measurement constructs, However; most of the measurement scales in this study showed excellent performance with Cronbach's 
alpha values more than 0.9 (Harris and Davison, 1999). Refer to Table 7 for the result.

\subsection{Factor Analysis of Attitude Toward Online Shopping}

Attitude items were run through exploratory factor analysis. The analysis was conducted on attitude items in terms of data sets obtained from the responses, which suggested a two-factor solution. The two-factor solution explained $75 \%$ of the variance. The orthogonal factor dimensions were identified through the use of principal component and varimax rotation procedures. For factor extraction, the latent criterion of 1.0 was used whereas for item inclusion, the factor loadings of 0.40 were used (Hair et al., 1992).

The individual construct composite reliability was investigated to determine the internal consistency of indicators that measure the underlying factors (Fornell and Larcker, 1981). Netemeyer et al. (2003) suggested that a factor is reliable when its composite reliability is revealed to be higher than 0.60 . The Cronbach's alpha for the two dimensions ranged from acceptable to very good. The first dimension of the Cronbach's alpha coefficient was 0.966 , indicating a very good reliability. The second dimension $(0.821)$ also illustrated very good reliability. The statements' reliability was deemed to be good and can hence produce the same results in repetitive tests. Result is presented in Table 8.

\subsection{Factor Analysis of Trust in Online Shopping}

The trust items concerning online shopping was exposed to exploratory analysis. The analysis conducted on the data set formed by the responses suggested a one-factor solution. The factor solution explained $70 \%$ of the variance. Both procedures of principal component and Varimax rotation were employed to determine orthogonal factor dimensions. The latent root criterion of 1.0 was employed for factor extraction while the factor loadings of 0.40 were used for item inclusion, as recommended by Hair et al. (1992).

The factor's composite reliability for each construct was examined to test the internal consistency of indicators that measure the underlying factors (Fornell and Larcker, 1981). Netemeyer et al. (2003) suggested that a factor is reliable when its composite reliability is revealed to be higher than 0.60 . The Cronbach's alpha for trust was very good at 0.94 . The statements' reliability was deemed to be good and can hence produce the same results in repetitive tests. The Cronbach's alpha coefficient for the trust items is displayed in Table 9.

Table 7. Reliability for study's variables

\begin{tabular}{|c|c|c|c|c|c|c|}
\hline Construct & Instrument & Dimensions & $\begin{array}{l}\text { Original } \\
\text { alpha }\end{array}$ & $\begin{array}{l}\text { Alpha } \\
\text { (pilot test) }\end{array}$ & $\begin{array}{l}\text { Alpha } \\
\text { (main sample) }\end{array}$ & $\begin{array}{l}\text { No. of } \\
\text { items }\end{array}$ \\
\hline \multirow[t]{3}{*}{ Attitude } & \multirow[t]{3}{*}{ Sun et al. (2011) } & Behavioral & 0.826 & 0.837 & 0.821 & 2 \\
\hline & & Affective & 0.826 & 0.811 & 0.928 & 6 \\
\hline & & Cognitive & 0.923 & 0.727 & 0.947 & 6 \\
\hline \multirow[t]{5}{*}{ Culture } & \multirow[t]{5}{*}{ Yoo et al. (2011) } & Power distance & 0.910 & 0.534 & 0.836 & 5 \\
\hline & & Uncertainty avoidance & 0.880 & 0.841 & 0.984 & 5 \\
\hline & & Individualism & 0.850 & 0.828 & 0.914 & 6 \\
\hline & & Long-term orientation & 0.790 & 0.888 & 0.858 & 6 \\
\hline & & Masculinity & 0.840 & 0.709 & 0.749 & 4 \\
\hline Perceived risk & Sitkin and Weingart (1995) & Uni-dimensional & 0.750 & 0.815 & 0.928 & 3 \\
\hline E-Service quality & Parasuraman et al. (2005) & Efficiency & 0.940 & 0.852 & 0.972 & 8 \\
\hline (E-S-QUAL scale) & & System availability & 0.830 & 0.608 & 0.886 & 4 \\
\hline E-Service quality & & Fulfillment & 0.890 & 0.713 & 0.941 & 7 \\
\hline \multirow[t]{4}{*}{ (E-RecS-QUAL scale) } & & Privacy & 0.830 & 0.874 & 0.941 & 3 \\
\hline & & Responsiveness & 0.880 & 0.890 & 0.904 & 5 \\
\hline & & Compensation & 0.770 & 0.796 & 0.796 & 3 \\
\hline & & Contact & 0.810 & 0.903 & 0.897 & 3 \\
\hline Trust & Harris and Goode (2004) & Uni-dimensional & 0.814 & 0.797 & 0.907 & 3 \\
\hline
\end{tabular}


Table 8. Factor analysis of attitude toward online shopping

\begin{tabular}{|c|c|c|c|c|}
\hline Factor & Factor loading & Eigen & Variance explained & Alpha \\
\hline Dimension ONE & & 9.399 & 67.137 & 0.966 \\
\hline I believe that adopting online shopping is & 0.898 & & & \\
\hline I believe that adopting online shopping is & 0.888 & & & \\
\hline I believe that online shopping is & 0.867 & & & \\
\hline I feel ___ toward online shopping & 0.860 & & & \\
\hline I feel ___ while using online shopping & 0.849 & & & \\
\hline I believe that online shopping is & 0.841 & & & \\
\hline I feel ___ toward online shopping & 0.812 & & & \\
\hline I believe that it is __ to shop online & 0.809 & & & \\
\hline I feel ___ while using online shopping & 0.800 & & & \\
\hline I feel ___ with the online shopping security & 0.753 & & & \\
\hline I believe that it is __ to shop online & 0.737 & & & \\
\hline I feel ___ with the online shopping security. & 0.719 & & & \\
\hline Dimension TWO & & 1.145 & 8.180 & 0.821 \\
\hline I am___ to shop online & 0.944 & & & \\
\hline I am___ to shop online & 0.800 & & & \\
\hline
\end{tabular}

Table 9. Factor analysis of trust in online shopping

\begin{tabular}{llll}
\hline Factor & Factor loading & Eigen & $\begin{array}{c}\text { Variance } \\
\text { explained }\end{array}$ \\
\hline Dimension & & 5.67 & 70.876 \\
E-retailer is genuinely committed to my satisfaction. & 0.923 & 0.94 \\
In my experience e- retailer is very reliable. & 0.889 & \\
I feel I know what to expect from e-retailer. & 0.882 & \\
There are no limits to how far e-retailer will go to solve a & & \\
service problem I may have. & 0.842 & \\
E-retailer is interested in more than just selling me goods and & & \\
making a profit. In other word, e-retailer try to make me happy. & 0.835 & \\
If e-retailer makes a claim or promise about its product, it is & & \\
probably true. & 0.831 & \\
Most of what e-retailer says about its products is true. & & \\
I think some of e- retailer's claims about its service are exaggerated. & 0.593 & \\
\hline
\end{tabular}

\section{CONCLUSION}

The primary aim of the study was to examine the factors that affect attitude of consumers towards Internet shopping in Malaysia and Saudi Arabia and how they affect purchase attitude. It also aimed to investigate the moderating impact of risk on the eservice quality-consumers' trust relationship in Malaysia and Saudi Arabia.

The findings revealed that service quality was relatively significant in its impact on consumer trust in online shopping, proving the proposed positive direct impact of perceived service quality upon customer trust. However, perceived risk was revealed to be linked with consumer trust towards online shopping, contrary to the proposed hypothesis. According to the results, trust in online retailer was positively associated with the attitude of consumers to online shopping. Therefore, marketers and managers should take into close consideration the requirements of trust development in online retailing. Finally, trust based on e-service quality is considered as the most suitable environment for developing favorable consumer attitude towards online shopping.

This study also contributed to the field of service quality expectations relationship with online shopping in the context of developing countries. It also examined the impact of culture on the service quality consumer expectations in both Malaysia and Saudi Arabia. This study may be different from prior works owing to its expanded scope but not unlike any study, it also has limitations that have to be kept in mind when interpreting and generalizing the results. Antecedent factors that may affect trust should be determined in future studies to provide an in-depth insight into this field. These factors may include Internet shopping, age, gender and income. This study measured 
students' overall attitudes toward online retailers and did not focus on the specific industry or vendor. The general opinion might not reflect the actual performance of each online retailer. In this study's survey, respondents were requested to complete a paper-based survey and to recollect past experiences on the factors influencing attitude. This study could be enhanced if the survey was carried out to concurrently assess the reactions of the respondents to specific site features while they interact with the site.

On the basis of the increasing e-commerce development in online shopping, various areas have appeared. Despite the validation of majority of the hypothesized relationships, the proposed model produced a relatively high degree of multiple determination coefficients. The resulting $\mathrm{R}^{2}$ value showed a need to determine additional variables to enhance the ability of the model to predict potential customer attitude toward online shopping. Future studies could extend the present one by employing a longitudinal setting to provide different insights, for example, by examining whether or not specific effects increase/decrease over time. This study is the pioneering study that examined consumers' risk as a moderator in the analysis of e-service qualitytrust relationship in Internet shopping. Despite the fact that the present study managed to reveal a moderating effect of risk on consumer's purchase attitude, more empirical support is required. An in-depth examination in this area and other risk related factors are suggested to achieve a more extensive understanding of consumers' risk-trust relationship in an online shopping context. The attitude antecedent showed direct and indirect impacts and differences in online spending. The effect of additional factors including satisfaction, loyalty and interactivity and the moderating effect of various demographic factors like income, age, gender and e-shopping experience should be kept into consideration in future studies.

\section{ACKNOWLEDGEMENT}

The authors are thankful to Dr. Faridahwati Mohammad Shamsudin and Dr. Azahari Ramli for their constant help and motivation for this study. We would also like to thank Dr. Sulaiman Althuaib for his continuous support during the data collection process.

\section{REFERENCES}

Ajzen, I., 1988. Attitudes, Personality and Behavior. 1st Edn., Dorsey, Chicago.
Ajzen, I., 1989. Attitude, Personality and Behavior. 1st Edn., Open University Press, Milton Keynes.

Ajzen, I., 1991. The theory of planned behavior. Organiz. Behav. Human Decision Processes, 50: 179-211. DOI: 10.1016/0749-5978(91)90020-T

Ajzen, I. and M. Fishbein, 1980. Understanding Attitudes and Predicting Social Behavior. 1st Edn., Prentice-Hall, Englewood Cliffs, ISBN-10: 0139364439, pp: 278.

Ajzen, I. and M. Fishbein, 2005. The Influence of Attitudes on Behavior. In: The Handbook of Attitudes, Albarracín, D., B.T. Johnson and M.P. Zanna (Eds.)., Lawrence Erlbaum Associates, Mahwah, NJ., ISBN-10: 0805844937, pp: 173-221.

Assael, H. 1995. Consumer Behavior and Marketing Action. 1st Edn., Kent Publishing Company, Boston, MA.

Babbie, E.R., 2004. The Practice of Social Research. 1st Edn., Wadsworth Thomson Learning, Belmont, CA.

Bain, R., 1929. The validity of life histories and diaries. J. Educ. Sociol., 3: 150-164.

Bechhofer, F. and L. Paterson, 2000. Principles of Research in the Social Sciences. 1st Edn., Routledge, London.

Berry, L.L. and A. Parasuraman, 1991. Marketing Services: Competing through Quality. 1st Edn., The Free Press, New York, ISBN-10: 002903079X.

Boss, R.W., 1978. Trust and managerial problem solving revisited. Group Organiz. Stud., 3: 331-342. DOI: 10.1177/105960117800300306

Carmines, E. and R. Zeller, 1979. Reliability and Validity Assessment. 1st Edn., Sage Publications, Beverly Hills, CA.

Chang, M.K., W. Cheung and V.S. Lai, 2005. Literature derived reference models for the adoption of online shopping. Inform. Manage., 42: 543-559. DOI: 10.1016/j.im.2004.02.006

Cheung, C.M., L. Zhu, T. Kwong, G.W. Chan and M. Limayem, 2003. Online consumer behavior: A review and agenda for future research. Proceedings of the 16th Bled E-Commerce Conference, (ECC' 03), Prentice-Hall/Financial Times, pp: 194-218.

Childers, T., C. Carr, J. Peck and S. Carson, 2001. Hedonic and utilitarian motivations for online retail shopping behavior. J. Retail., 77: 511-535. DOI: 10.1016/S0022-4359(01)00056-2

Cho, J., 2004. Likelihood to abort an online transaction: Influences from cognitive evaluations, attitudes and behavioral variables. Inform. Manage., 41: 827-838. DOI: 10.1016/j.im.2003.08.013 
Choi, J. and L.V. Geistfeld, 2004. A cross-cultural investigation of consumer e-shopping adoption. J. Econom. Psychol., 25: 821-838. DOI: 10.1016/j.joep.2003.08.006

Cooper, D.R. and P.S. Schindler, 2006. Business Research Methods. 1st Edn., McGraw-Hill, New York.

Corritore, C.L., B. Kracher and S. Wiedenbeck, 2003. On-line trust: Concepts, evolving themes, a model. Int. J. Human Comput. Stud., 58: 737-758. DOI: 10.1016/S1071-5819(03)00041-7

Crocker, L. and J. Algina, 1986. Introduction to Classical and Modern Test Theory. 1st Edn., Holt, Rinehart and Winston, New York, pp: 527.

Cronbach, L.J., 1951. Coefficient alpha and the internal structure of tests. Psychometrika, 16: 297-334. DOI: $10.1007 / \mathrm{BF} 02310555$

Davis, F.D., R.P. Bagozzi and R.R. Warshaw, 1989. User acceptance of computer technology: A comparison of two theoretical models. Manage. Sci., 35: 982-1003. DOI: $10.1287 / \mathrm{mnsc} .35 .8 .982$

Doney, P. and J. Cannon, 1997. An examination of the nature of trust in buyer-seller relationships. J. Market., 61: 35-51. DOI: 10.2307/1251829

Eastin, M.S., 2002. Diffusion of e-commerce: An analysis of the adoption of four e-commerce activities. Telemat. Informat., 19: 251-267. DOI: 10.1016/S0736-5853(01)00005-3

Edwards, A. and R. Talbot, 1999. The Hard-Pressed Researcher: A Research Handbook for the Caring Professions. 2nd Edn., Longman, New York, ISBN10: 058236972X, pp: 222.

Fishbein, M., 1963. An investigation of the relationships between beliefs about an object and the attitude toward that object. Human Relat., 16: 233-279. DOI: 10.1177/001872676301600302

Fishbein, M. 1967. Attitude and the Prediction of Behavior. In: Readings in Attitude Theory and Measurement, Fishbein, M. (Ed.), Wiley, New York.

Fishbein, M. and I. Ajzen, 1975. Belief, Attitude, Intention and Behavior: An Introduction to Theory and Research. 1st Edn., Addison-Wesley, Reading, MA, pp: 45.

Fornell, C. and D. Larcker, 1981. Evaluating structural equation models with unobservable variables and measurement error. J. Market. Res., 18: 39-50. DOI: $10.2307 / 3151312$

Fraenkel, J.R. and N.E. Wallen, 2003. How to design and evaluate research in education. 5th Edn., McGrawHill, Boston.
Hair, J.F., R.E. Anderson, R.L. Tatham and W.C. Black, 1992. Multivariate Data Analysis with Readings. 3rd Edn., Macmillian Publishing Company, New Jersey, ISBN-10: 002348750X, pp: 544.

Hair, J.F., W.C. Black, B.J. Babin and R.E. Anderson, 2010. Multivariate Data Analysis: A Global Perspective. Pearson Education, Inc., New Jersey, ISBN-10: 0135153093, pp: 800.

Hair, J.F., C.W. Lamb and C.D. McDaniel, 2000. Marketing. 1st Edn., South-Western Publishing, Cincinnati, Ohio.

Hale, J.L., B.J. Householder and K.L. Greene, 2002. The Theory of Reasoned Action. In: The persuasion handbook: Developments in Theory and Practice, Dillard, J.P. and M. Pfau, (Eds.). Sage, Thousand Oaks, ISBN-10: 1412976049, pp: 259-286.

Harris, L.C. and M.M. Goode, 2004. The four levels of loyalty and the pivotal role of trust: A study of online service dynamics. J. Retail., 80: 139-158. DOI: 10.1016/j.jretai.2004.04.002

Harris, R. and D. Davison, 1999. Anxiety and involvement: Cultural dimensions of attitudes toward computers in developing societies. J. Global Inform. Manage., 7: 26-38.

Hassanein, K. and M. Head, 2007. Manipulating perceived social presence through the web interface and its impact on attitude towards online shopping. Int. J. Human Comput. Stud., 65: 689-708. DOI: 10.1016/j.ijhcs.2006.11.018

Heise, D.R., 1970. Causal inference from panel data. Sociol. Methodol., 2: 3-27. DOI: 10.2307/270780

Hess, J.S., 1995. Construction and assessment of a scale to measure consumer trust.

Jarvenpaa, S.L., 2000. Consumer trust in an Internet store. Inform. Manage. Technol., 1: 45-71. DOI: 10.1023/A:1019104520776

Johnson-George, C. and W. Swap, 1982. Measurement of specific interpersonal trust: Construction and validation of a scale to assess trust in a specific other. J. Personality Soc. Psychol., 43: 1306-1317. DOI: 10.1037/0022-3514.43.6.1306

Joshi, A.W., and R.L. Stump, 1999. The contingent effect of specific asset investments on joint action in manufacturer-supplier relationships: An empirical test of the moderating role of reciprocal asset investments, uncertainty and trust. J. Acad. Market. Sci., 27: 291-305. DOI: $10.1177 / 0092070399273001$ 
Kee, H.W. and R.E. Knox, 1970. Conceptual and methodological considerations in the study of trust and suspicion. J. Conflict Resolut., 14: 357-365. DOI: 10.1177/002200277001400307

Krech, D., R.S. Crutchfield and E.L. Ballachey, 1962. Individual in Society: A Textbook of Social Psychology. 1st Edn., McGraw-Hill, New York.

Li, N. and P. Zhang, 2002. Consumer online shopping attitudes and behavior: An assessment of research. Proceedings of 8th American Conference on Information Systems, Aug. 9-11, pp: 508-517.

Liang, T.P. and H.J. Lai, 2002. Effect of store design on consumer purchases: An empirical study of on-line bookstores. Inform. Manage., 39: 431-444. DOI: 10.1016/S0378-7206(01)00129-X

Lumley, F.E., 1928. Principles of Sociology. 1st Edn., McGraw-Hill, New York.

Mayer, R.C., J.H. Davis and F.D. Schoorman, 1995. An integrative model of organizational trust. Acad. Manage. Rev., 20: 709-734.

McKnight, D.H. and N.L. Chervany, 2001. What trust means in e-commerce customer relationships: An interdisciplinary conceptual typology. J. Electron. Commerce, 6: 35-60.

Moorman, C., G. Zaltman and R. Deshpandé, 1992. Relationships between providers and users of market research: The dynamics of trust within and between organizations. J. Market. Res., 29: 314-29.

Morgan, R.M. and S.D. Hunt, 1994. The commitmenttrust theory of relationship marketing. J. Market., 58: 20-38. DOI: 10.2307/1252308

Netemeyer, R.G., W.O. Bearden and S. Sharma, 2003. Scaling Procedures: Issues and Applications. Sage Publications, Thousand Oaks, CA., ISBN-10: 0761920269, pp: 224.

North, C.C., 1932. Social problems and social planning. New York: McGraw Hill Book Co. pp. 6-7.

Osgood, C.E., G.J. Suci and P.H. Tannenbaum, 1957. The Measurement of Meaning. 1st Edn., University of Illinois Press, Urbana, ISBN-10: 0252745396, pp: 342.

Ostrom, T.M., 1969. The relationship between the affective, behavioral and cognitive components of attitude. J. Exp. Soc. Psychol., 5: 12-30. DOI: 10.1016/0022-1031(69)90003-1

Parasuraman, A., V.A. Zeithaml and A. Malhotra, 2005. E-S-Qual: A multiple-item scale for assessing electronic service quality. J. Service Res., 7: 213233. DOI: $10.1177 / 1094670504271156$
Pike, 2008. Destination Marketing. Elsevier Inc., Oxford, UK.

Pritchard, M.P., M.E. Havitz and D.R. Howard, 1999. Analyzing the commitment-loyalty link in service contexts. J. Acad. Market. Sci., 27: 333-348. DOI: 10.1177/0092070399273004

Rocereto, J.F. and J.B. Mosca, 2012. The differential roles of product brand image and store brand image in retail loyalty: A self-concept image congruity perspective. J. Bus. Econom. Res., 10: 77-95.

Rosenberg, M.J. and C.I. Hovland, 1960. Attitude Organization and Change: An Analysis of Consistency. 1st Edn., Yale University Press, New Haven, CT.

Sarantakos, S., 1997. Social Research. 1st Edn., Macmillan Education Australia Pty Ltd, Melbourne.

Saunders, A., J. Werner, E.D. Andrulis, T. Nakayama and S. Hirose et al., 2003. Tracking FACT and the RNA Polymerase II Elongation Complex Through Chromatin in Vivo. Science, 301: 1094-1096. DOI: 10.1126/science. 1085712

Schiffman, L. and L.L. Kanuk, 2004. Consumer Behavior. 8th Edn., Prentice Hall, Upper Saddle River, NJ.

Schiffman, M., P.E. Castle and J. Jeronimo, 2007. Human papillomavirus and cervical cancer. Lancet, 370: $\quad 890-907$. DOI: 10.1016/S01406736(07)61416-0, PMID: 17826171

Sekaran, U. 2003. Research Methods for Business: A Skill Building appr006Fach. 1st Edn., John Wiley and sons, Inc., USA.

Shimp, T.A. and A. Kavas, 1984. The theory of reasoned action applied to coupon usage. J. Consumer Res., 11: 795-809. DOI: $10.1086 / 209015$

Sitkin, S.B. and L.R. Weingart, 1995. Determinants of risky decision-making behavior: A test of the mediating role of risk perceptions and propensity. Acad. Manage. J., 38: 1573-1592. DOI: $10.2307 / 256844$

Sivasailam, N., D.J. Kim and H.R. Rao, 2002. What companies are(n't) doing about Web site assurance. IEEE IT Profess., 4: 33-40. DOI: 10.1109/MITP.2002.1008535

Smith, R.E. and W.R. Swinyard, 1983. Attitude-behavior consistency: The impact of product trial versus advertising. J. Market. Res., 20: 257-267. DOI: $10.2307 / 3151829$

Stewart, D.W., 1981. The application and misapplication of factor analysis in marketing research. J. Market. Res., 18: 51-62. DOI: 10.2307/3151313 
Sun, J., P. Ahluwalia and K.S. Koong, 2011. The more secure the better? A study of information security readiness. Indus. Manage. Data Syst., 111: 570-588. DOI: 10.1108/02635571111133551

Tull, D.S. and G.S. Albaum, 1973. Survey Research: A Decisional Approach. 1st Edn., Intent Educational Publishers, New York, ISBN-10: 070022436X, pp: 244.

Verhoef, P.C. and F. Langerak, 2001. Possible determinants of consumers' adoption of electronic grocery shopping in the Netherlands. J. Retail. Consumer Services, 8: 275-285. DOI: 10.1016/S0969-6989(00)00033-3
Vijayasarathy, L.R., 2002. Product characteristics and internet shopping intentions. Internet Res., 12: 411 426. DOI: $10.1108 / 10662240210447164$

Yoo, B., N. Donthu and T. Lenartowicz, 2011. Measuring Hofstede's five dimensions of cultural values at the individual level: Development and validation of CVSCALE. J. Int. Consumer Market., 23: 193-210. DOI: 10.1080/08961530.2011.578059

Zimbardo, P.G. and J.N. Boyd, 1999. Putting time in perspective: A valid, reliable individual differences metric. J. Personality Soc. Psychol., 77: 1271-1288. DOI: 10.1037/0022-3514.77.6.1271 